EUROPA REGIONUM TOM XXVIII ROK 2016

DOI: $10.18276 /$ er.2016.28-16

\author{
AnTONi MiCKIEWICZ, BARTOSZ MiCKIEWICZ \\ Zachodniopomorski Uniwersytet Technologiczny w Szczecinie
}

\title{
Właściwości inwestycji w gospodarstwach położonych na obszarach Natura 2000
}

\section{Wprowadzenie}

D ocząwszy od początku lat 90. ub.w. wspólna polityka rolna zmierzała w kierunku sprostania nowemu celowi związanym z zrównoważonym rozw ojem. Ewolucja polegała na przejściu od polityki opartej na podtrzymywaniu cen i wspieraniu produkcji, do polityki bezpośredniego wsparcia rolników i zwiększenia środków na rozwój obszarów wiejskich. W tym celu opracowano pakiet reform Agenda 2000, w którym zwrócono uwagę na korzyści ekologiczne wynikające z poprawy stanu środowiska, ochrony zasobów naturalnych, czy poprawa stanu krajobrazu wiejskiego. Obecnie Wspólna Polityka Rolna określiła trzy priorytetowe obszary działań mających na celu ochronę i wzmocnienie dziedzictwa obszarów wiejskich, w tym:

- utrzymanie różnorodność biologiczna oraz zachowanie i rozwój naturalnych systemów rolnictwa oraz tradycyjnych krajobrazów rolniczych,

- właściwe prowadzenie gospodarki wodnej,

- radzenie sobie ze zmianami klimatu.

Przyjęta w 1992 r. dyrektywa Rady w sprawie ochrony siedlisk naturalnych oraz dzikiej fauny i flory miała na celu wspieranie zachowanie różnorodności biologicznej przy uwzględnieniu wymagań gospodarczych, społecznych, kulturowych i regionalnych. Na ogółuważa się, że stanowi fundament polityki ochrony przyrody, a wraz z dyrektywą ptasią ustanowiła szeroką sieć obszarów chronionych Natura 
2000, która zabezpieczała przed potencjalnie szkodliwymi zmianami. Tak więc ochrona przyrody zbudowana jest na dwóch filarach, to jest na sieci Natura 2000 oraz systemu ścisłej ochrony gatunkowej. W sumie dyrektywa chroni ponad 1 tys. gatunków roślin i zwierząt oraz ponad 200 siedlisk (np. specjalne typy lasów, łąk, mokradeł, bagien). Dyrektywy ptasia i siedliskowa musiały ewoluować w celu odzwierciedlenia kolejnych rozszerzeń Unii Europejskiej, co wyrażało się późniejszymi regulacjami ${ }^{1}$.

Strategia ochrony różnorodności biologicznej UE miała na celu powstrzymanie utraty różnorodności biologicznej i funkcji ekosystemu oraz pomoc $\mathrm{w}$ powstrzymaniu utraty różnorodności biologicznej do roku 2020. Odzwierciedla on zobowiązania podjęte przez UE w $2010 \mathrm{r}$. w ramach międzynarodowej konwencji o różnorodności biologicznej. Sieć Natura 2000 nie jest systemem ścisłych rezerwatów przyrody, zktórego byłyby wyłączone wszystkie działania człowieka. Choć obejmuje ściśle chronione rezerwaty przyrody, większość ziemi pozostaje własnością prywatną. Podejście do ochrony i zrównoważonego użytkowania obszarów Natura 2000 jest znacznie szersze, w dużej mierze koncentruje się na ludziach pracujących z naturą, a nie przeciwko niej. Jednakże państwa członkowskie muszą zapewnić, że tereny są zarządzane w sposób zrównoważony, zarówno pod względem ekologicznym i ekonomicznym ${ }^{2}$.

\section{Problematyka, cele i zakres badań}

Działania związane z inwestycjami na obszarach Natura $2000 \mathrm{w}$ okresie programowania 2007-2013 wchodziły w skład programu rolnośrodowiskowego, jako dwa wyodrębnione pakiety związane z ochroną zagrożonych gatunków ptaków i siedlisk na obszarach Natura 2000 i poza obszarami Natura 2000. Środki pochodzące z EFRROW stanowily rekompensatę dla utrudnienia gospodarowania na terenach wrażliwych przyrodniczo. Obecnie stanowią nowy instrument wsparcia w ramach II filara WPR, obejmującą okres programowania na lata 2014-2020. Został powiązany z inwestycjami w środki trwałe. W nowym PROW 2014-2020 wyodrębniono poddziałanie „Pomoc na inwestycje w gospodarstwach rolnych”, który obejmuje trzy typy operacji: modernizacje gospodarstw rolnych, inwestycje w go-

\footnotetext{
${ }^{1}$ C. Coffey, S. Richartz, The EU Habitats Directive, Generating Strong Responses, Institute for European Environmental Policy. 2003.

${ }^{2}$ J. Mehtata, T. Vuorisalo, Conservation policy and the EU Habitats Directive: favorable conservation status as a measure of conservation success, Environmental Policy and Governance. 2007.
} 
spodarstwach położonych na obszarach Natura 2000 oraz inwestycje w gospodarstwach położonych na obszarach OSN. Wsparcie adresowane do gospodarstw położonych na obszarach Natura 2000, skierowane jest do beneficjentów, którzy napotykają na szereg wymogów związanych z obowiązkiem realizacji zadań ochronnych przewidzianych dla danego obszaru.

Już w przeszłości Wspólna Polityka Rolna określała priorytetowe obszary działań w celu ochrony i wspierania naturalnego dziedzictwa obszarów wiejskich. Podstawą działania było zachowanie różnorodności biologicznej oraz rozwój naturalnych systemy rolnictwa. Plany ochrony obszarów Natura 2000 skierowane zostały do gospodarstw funkcjonujących na trwałych użytkach zielonych oraz do gospodarstw prowadzących produkcję zwierzęcą zgodnie z wymogami ochrony środowiska.

Podstawowym celem opracowania była prezentacja specyfiki nowej operacji typu inwestycje w gospodarstwach położonych na obszarach Natura 2000, na tle rozwiązań prawnych UE, które swoimi korzeniami sięgają $1979 \mathrm{r}$. Podstawową rolę regulacyjną spełniały tzw. dyrektywa ptasia i siedliskowa, w których zwracano uwagę na negatywne zmiany zachodzące na obszarach wiejskich. Ponadto przedstawiono sposoby ukierunkowania pomocy dla beneficjentów, grupy podmiotów uprawnionych do utrzymania wsparcia oraz wysokość środków przeznaczonych na dofinansowanie inwestycji.

Badania oparto na ustawodawstwie europejskim, które odgrywa podstawową rolę w strukturze Wspólnoty, przy rozstrzyganiu kierunków postępowania zmierzającego do osiągnięcia zamierzonego celu. Na bazie tych rozstrzygnięć budowano prawodawstwo krajowe, kierowane do różnych instytucji i organizacji, odpowiedzialnych za kwestie ochrony środowiska.

\section{Charakterystyka dyrektywy siedliskowej i ptasiej w ustawodawstwie europejskim}

Sieć ekologiczna Natura 2000 była tworzona w oparciu o dwie dyrektywy, w tym dyrektywy tzw. ptasiej przyjętej w 1979 r. oraz dyrektywy siedliskowej z 1992 r. Celem dyrektywy siedliskowej było przyczynienie się do zapewnienia różnorodności biologicznej, poprzez ochronę siedlisk przyrodniczych oraz dzikiej fauny i flory na europejskim terytorium wspólnoty. Zadanie to miało być realizowane, poprzez ochronę siedlisk zagrożonych lub reprezentatywnych dla poszczególnych regionów biogeograficznych. Do niezmiernie ważnych zadań zaliczono zachowanie roślin i zwierząt rzadkich i zagrożonych, realizowaną poprzez ochronę 
gatunkową i ochronę ich siedlisk. Działania podejmowane zgodnie z dyrektywą powinny uwzględniać wymogi gospodarcze, społeczne i kulturalne oraz cechy regionalne i lokalne. Duże znaczenie miał proces tworzenia spójnej europejskiej sieci ekologicznej specjalnych obszarów ochrony, pod nazwą Natura 2000. Sieć ta, złożona z obszarów, w których znajdują się różne rodzaje siedlisk przyrodniczych i siedliska gatunków, powinna umożliwić zachowanie tych typów siedlisk w niezmienionym kształcie. Każde państwo członkowskie zostało zobowiązane do tworzenia sieci Natura 2000, proporcjonalnie do reprezentacji na jego terytorium siedlisk przyrodniczych. W tym celu każde państwo członkowskie zostało zobowiązane do wyznaczenia specjalnych obszarów ochrony $(\mathrm{SOO})^{3}$.

Stan ochrony siedliska przyrodniczego oznacza sumę oddziaływań na siedlisko przyrodnicze i jego typowe gatunki. Oddziaływania te mogą mieć wpływ na rozmieszczenie, strukturę i funkcjonowanie tego siedliska, a w odniesieniu do stanu ochrony gatunków - wpływ na rozmieszczenie i wielkość populacji. Wśród gatunków, będących przedmiotem zainteresowania Wspólnoty, są gatunki podatne na zagrożenie a więc takie które w najbliższej przyszłości mogą stać się zagrożonymi, rzadkie endemiczne i wymagające specjalnej uwagi na charakter ich siedliska. Obszar o znaczeniu wspólnotowym jest to ostoja, która w znaczący sposób przyczynia się do zachowania lub odtworzenia stanu sprzyjającego ochronie środowiska przyrodniczego ${ }^{4}$.

W ramach omawianych dyrektyw państwa są zobowiązane do odpowiedniego postępowania. Oprócz potrzeby zachowania korytarzy ekologicznych (np. dolin rzecznych), stawów czy wyspowych fragmentów zadrzewień, państwa członkowskie są zobowiązane do przestrzegania wpływu inwestycji na tych obszarach.

Podjęte reformy w ramach Agendy 2000 stanowily znaczący krok naprzód w realizacji niezbędnych instrumentów zmierzających do ochrony środowiska naturalnego. Przyjęto jako zasadę, że wspólna polityka rolna zostanie skierowana na promowanie zrównoważonego rolnictwa, przy czym powinna ona odzwierciedlać obok funkcji produkcyjnych, również funkcje środowiskowe i społeczne. Interpretując te regulacje, można powiedzieć, że działania rolnośrodowiskowe miały okazać się kluczowym elementem integracji ochrony środowiska. Z kolei wsparcie finansowe miało zachęcać rolników do ochrony i poprawy stanu środowiska, poprzez przyjęcie przyjaznych dla środowiska technik rolniczych, które wykraczały poza

\footnotetext{
${ }^{3}$ Dyrektywa Rady 92/43/EWG z dnia 21 maja 1992 r. w sprawie ochrony siedlisk przyrodniczych oraz dzikiej fauny i flory.

${ }^{4}$ Dyrektywa Rady z dnia 2 kwietnia 1979 r. w sprawie ochrony dzikiego ptactwa.
} 
obowiązujące przedtem zobowiązania prawne. W zamian rolnicy otrzymywali płatności, które powinny zapewniać rekompensaty ponoszenia dodatkowych kosztów i utraconych dochodów, wynikających ze stosowania tych praktyk rolniczych przyjaznych dla środowiska. Spodziewano się, że działania rolnośrodowiskowe odegrają kluczową rolę w stosunku do oczekiwań społeczeństwa na poprawę środowiskowa naturalnego. Cel ten zamierzano osiągnąć poprzez rozbudowanie zróżnicowanych systemów gospodarowania, utrzymanie mozaiki krajobrazowej, a ponadto podjęcie przyjaznych dla środowiska technik hodowli i innych poczynań z tym związanych. W regulacjach UE wskazywano, że należy wspierać przyjazny dla środowiska proces ekstensyfikacji rolnictwa, większe dbanie o otocznie rolnictwa i siedliska naturalnego. Wskazano, że wsparcie zostanie przyznane rolnikom, którzy zobowiążą się do stosowania praktyk rolnośrodowiskowych przez okres co najmniej 5 lat. Zobowiązania rolnośrodowiskowe będą obejmowały więcej niż tylko stosowanie zwyczajnej dobrej praktyki rolniczej, ale będzie poszerzone o poczynania innowacyjne. Ideę wsparcia oparto o następujące zasady wynikających z:

1) utraconych dochodów,

2) dodatkowych kosztów wynikających z tego zobowiązania oraz

3) potrzeby zapewnienia zachęty dla beneficjentów. Ponadto należy brać pod uwagę koszt znacznych niedochodowych prac podejmowanych wgospodarstwie, a niezbędnych dla wypetnienia zobowiązań.

W rozporządzeniu Rady (WE) nr 1698/2005 w sprawie wsparcia rozwoju obszarów wiejskich przez EFRROW stwierdzono, że celem działania rolnośrodowiskowego jest potrzeba wspieranie szybszego wdrażania przez rolników spełnianie norm opartych na prawodawstwie wspólnotowym. Normy te dotyczyły środowiska naturalnego, zdrowia publicznego, zdrowia zwierząt i roślin oraz dobrostanu zwierząt. Normy te mogą nałożyć na rolników nowe obowiązki i w związku z tym powinno zostać udzielone wsparcie w celu pomocy w częściowym pokryciu dodatkowych kosztów lub utraconych dochodów, wynikających z tych obowiązków. W rozporządzeniu wskazano na konieczność szczególnego wsparcia zasad gospodarowania gruntami rolnymi, które powinno przyczynić się do zrównoważonego rozwoju poprzez zachęcanie rolników do stosowania metod użytkowania gruntów zgodnych z potrzebą zachowania środowiska naturalnego i krajobrazu oraz poprawy zasobów naturalnych. Płatności rolnośrodowiskowe były udzielane rolnikom, którzy dobrowolnie podejmowali zobowiązania rolnośrodowiskowe. W przypadku obszarów Natura 2000 wsparcie udzielane było rolnikom w celu rekompensaty poniesionych kosztów i utraconych dochodów wynikających z niedogodności funkcjonowa- 
nia na obszarach związanych z wdrażaniem dyrektywy siedliskowej i ptasiej. Inwestycje na tych obszarach traktowane były jako nieprodukcyjne, lecz mają przyczynić się do podwyższenia użyteczności publicznej obszaru Natura $2000^{5}$.

W nowej perspektywie finansowej 2014-2020 podtrzymano ideę przyznawania rolnikom wsparcia z tytułu wdrażania dyrektyw siedliskowej i ptasiej. Płatności dla obszarów Natura 2000 uzyskało status odrębnego poddziałania, w ramach dzialania inwestycje w środkitrwałe. Wsparcia powinno przyczynić się do skutecznego zarządzania obszarami Natura 2000, w sytuacji gdy inwestycje mają charakter nieprodukcyjny, związany z osiągnięciem celów rolnośrodowiskowych i klimatycznych. Pomoc powinna ponadto przyczynić się do podwyższenia użyteczności publicznej obszaru Natura 2000. Ponadto w celu zapewnienia odpowiedniego stosunku udziału trwałych użytków zielonych w całkowitej powierzchni użytków rolnych, należy wypracować odpowiednie metody określania tego stosunku ${ }^{6}$.

\section{Realizacja dyrektyw siedliskowej i ptasiej w warunkach polskich}

Obszary Natura 2000 tworzone były od momentu przystąpienia Polski do Unii Europejskiej (2004). Zgodnie z wymaganiami obu dyrektyw regulujących sieć Natura 2000, zapisy zostały przetransponowane do polskiego porządku prawnego. Powstała ustawa z 2004 r. o ochronie przyrody, miała charakter kompleksowy, obejmowała bowiem obok parków narodowych, rezerwatów przyrody, parków krajobrazowych, obszarów chronionego krajobrazu, również obszary Natura 2000 czy pomniki przyrody. Celem ochrony przyrody jest utrzymanie procesów ekologicznych i stabilności ekosystemów, zachowanie różnorodności biologicznej, ochrona walorów krajobrazowych i inne ${ }^{7}$. Sieć Natura 2000 oznacza obszar utworzony w celu ochrony populacji dziko występujących ptaków lub siedlisk przyrodniczych lub gatunków będących przedmiotem zainteresowania Wspólnoty. Sieć obszarów Natura 2000 obejmuje: obszary specjalnej ochrony ptaków (OSO),specjalne obszary ochrony siedlisk (SOO) oraz obszary mające znaczenie dla Wspólnoty. Powierzchnia specjalnych obszarów ochrony sie-

${ }^{5}$ Rozporządzenie Rady (WE) nr 1698/2005 z dnia 20 września 2005 r. w sprawie wsparcia rozwoju obszarów wiejskich przez Europejski Fundusz Rolny na rzecz Rozwoju Obszarów Wiejskich (EFRROW).

${ }^{6}$ Rozporządzenie Parlamentu Europejskiego i Rady (UE) NR 1305/2013 z dnia 17 grudnia 2013 r. w sprawie wsparcia rozwoju obszarów wiejskich przez Europejski Fundusz Rolny na rzecz Rozwoju Obszarów Wiejskich (EFRROW) i uchy lające rozporządzenie Rady (WE) nr 1698/2005.

${ }^{7}$ Ustawa z dnia 16 kwietnia 2004 r. o ochronie przyrody. 
dlisk (SOO) w 2011 r. wynosiła 3432,8 tys. ha, co stanowiło 11,0\% powierzchni ogólnej kraju. Z kolei powierzchnia obszarów specjalnej ochrony ptaków (OSO) wynosiła 4922,4 tys. ha co stanowiło 15,7\% powierzchni ogólnej Polski. Z uwagi na fakt, ze powierzchnia użytków rolnych spadła poniżej $50 \%$ powierzchni kraju, dlatego też w tym kontekście należy rozpatrywać istnienie sieci Natura 2000. Obszary te obejmują głównie trwałe użytki zielone (łąki i pastwiska), które charakteryzują się mniej intensywnymi metodami gospodarowania. Obszar Natura 2000 może obejmować część lub całość obszarów i obiektów objętych innymi formami ochrony przyrody. Największe natężenie występowania obszarów ochrony siedlisk na poziomie $22,4-27,5 \%$ występuje w woj. zachodniopomorskim, dolnośląskim, podlaskim i podkarpackim. Z kolei najmniejsze natężenia tego zjawiska występuje na Kujawach, Mazowszu i na ziemi lubelskiej.

Nadzór nad funkcjonowaniem polskiej sieci Natura 2000 sprawuje generalny dyrektor Ochrony Środowiska, natomiast regionalni dyrektorzy koordynują funkcjonowanie obszarów w zasięgu swojego działania.

W oparciu o dokumenty GDOŚ sieć Natura 2000 na terytorium Polski wyznaczona jest dla:

- 81 siedlisk przyrodniczych, w tym 18 siedlisk o priorytetowym znaczeniu dla Wspólnoty,

- 40 gatunków roślin, w tym 10 gatunków roślin o priorytetowym znaczeniu dla Wspólnoty,

- 80 gatunków zwierząt, w tym 12 gatunków zwierząt o priorytetowym znaczeniu dla Wspólnoty,

- 74 gatunków ptaków z dyrektywy ptasiej 183 gatunków ptaków wędrownych. Zjawisko gospodarowania na obszarach Natura 2000 ma swoje pozytywne i negatywne skutki. Wśród pozytywów można wymienić korzyści finansowe, jakie uzyskują rolnicy realizujący programy rolnośrodowiskowe. Głównym celem programu była poprawa jakości środowiska przyrodniczego na obszarach wiejskich, w tym w szczególności utrzymanie i przywracanie stanu najcenniejszych siedlisk poprzez promowanie zrównoważonego gospodarstwa oraz ochronę zagrożonych gatunków chronionych. Obszary te sprzyja rozwojowi agroturystyki, rekreacji i promowaniu rolnictwa ekologicznego. Do cech negatywnych można zaliczyć głównie ograniczenia w zakresie inwestowania. Przy podejmowaniu inwestycji należy posługiwać się opinią oddziaływania na środowisko. Dla obszarów Natura 2000 nie ustanawia się zakazów, tak jak dla innych form ochrony przyrody, np. parków narodowych. Ochrona na obszarach Natura 2000 opiera się przede wszystkim 
na ograniczaniu podejmowania działań mogących w znaczący sposób pogorszyć stan siedlisk przyrodniczych oraz siedlisk gatunków roślin i zwierząt, a także w znaczący sposób wpłynąć negatywnie na gatunki, dla których ochrony został wyznaczony obszar Natura $2000^{8}$.

\section{Instrumenty wsparcia finansowego $w$ ramach działania rolnośro- dowiskowego w części dotyczącej obszarów Natura 2000 (PROW 2007-2013)}

Działania rolnośrodowiskowe były kluczowym czynnikiem integracji problematyki ochrony środowiska do wspólnej polityki rolnej. Były zaprojektowane tak, aby zachęcić rolników do ochrony i poprawy stanu środowiska na ich polach uprawnych, płacąc im za świadczenie usług środowiskowych. W zamian rolnicy zobowiązani byli, przez minimalny okres co najmniej pięciu lat, do przyjmowania przyjaznych dla środowiska technik rolniczych, które wykraczały poza zobowiązania prawne. W zamian rolnicy otrzymywała płatności, które zapewniały rekompensatę dodatkowych kosztów i utraconych dochodów wynikających ze stosowania tych przyjaznych środowisku praktyk rolniczych, zgodnie z postanowieniami umów rolnośrodowiskowych. Środki rolnośrodowiskowe odgrywały kluczową rolę dla spełnienia zapotrzebowania społeczeństwa na efektywne środowisko przewidziane dla rolnictwa ekologicznego. Poprzez programy rolnośrodowiskowe państwo zmierzało do rozbudowania systemów gospodarowania, wprowadzenie mozaiki krajobrazów, przyjaznych sposobów uprawy, dostosowanych do potrzeb konkretnych regionów lub systemy wypasania. Tak więc płatności rolnośrodowiskowe miały zachęcać rolników do przyjęcia takiego poziomu intensywności produkcji, które nie zawsze były pierwszym wyborem z punktu widzenia opłacalności.

Programy rolnośrodowiskowe zaliczane były do jednych z ważniejszych poczynań, mających na celu poprawę jakości życia mieszkańców obszarów wiejskich, poprzez dbanie o jakość środowiska naturalnego. W Europie Zachodniej stosunkowo szybko spostrzeżono, że procesom intensyfikacji rolnictwa towarzyszyły negatywne zjawiska związane z pogarszaniem się stosunków wodnych, powietrza, gleby i krajobrazu. W 1991 r. ukazało się rozporządzenie EWG w sprawie produkcji ekologicznej produktów rolnych oraz ich znakowania, rozpoczynając formalny proces koncesjonowania obrotu i sprzedaży produktów ekologicznych.

${ }^{8}$ I. Kaługa, Korzyści dla rolnictwa wynikające z gospodarowania na obszarach Natura 2000, Ministerstwo Srodowiska. 2009. 
Programy rolnośrodowiskowe były jedną z form finansowej pomocy udzielanej rolnikom w trudnym okresie transformacji i przystosowania do wymogów wzajemnej zgodności. Program był inny niż pozostałe działania pomocowe, ponieważ jego głównym przesłaniem było zachowanie przyrody w niezmienionej formie. Dotychczas ochroną przyrody środowiska i krajobrazu zajmowali się biolodzy i przyrodnicy. Od 2004 r. rolnik mógł chronić przyrodę na terenie własnego gospodarstwa i otrzymywać wsparcie finansowe na tego typu działalność.

W perspektywie programowania, obejmującej lata 2007-2013 finansowanie działań w ramach PROW odbywało się za pośrednictwem EFRROW. Płatności rolnośrodowiskowe miały na celu utrzymanie zrównoważonego rozwoju obszarów wiejskich, co wiązało się przede wszystkim z poprawą stanu środowiska naturalnego, odpowiednim użytkowaniem gruntów oraz ochroną unikalnych zasobów naturalnych obszarów wiejskich. Część działań miała charakter rekompensaty z tytułu ograniczenia produkcji rolniczej prowadzonej na terenach chronionych (obszary NATURA 2000). Z kolei program rolnośrodowiskowy miałna celu poprawę środowiska przyrodniczego obszarów wiejskich poprzez zachowanie cennych siedlisk, promowanie zrównoważonego systemu gospodarowania, kształtowanie struktury krajobrazu, ochrony lokalnych ras zwierząt gospodarskich. Programy rolnośrodowiskowe obejmowały najpierw 9 pakietów. W każdym pakiecie występowały warianty, których wybór zobowiązywał do realizacji konkretnych, szczegółowych zadań określonych w regulacjach prawnych.

W 2009 r. do programu rolnośrodowiskowego wprowadzono kilka istotnych zmian w funkcjonowaniu programu, do których należały:

- usunięcie z listy pakietów do realizacji pakietu 9. „strefy buforowe”,

- wprowadzenie obowiązku rejestrowanie planu działalności rolnośrodowiskowej w systemie teleinformatycznym administrowanym przez Centrum Doradztwa Rolniczego w Brwinowie,

- poszerzenie zakresu prowadzenia przez rolnika rejestru działalności rolnośrodowiskowej, poprzez wprowadzenie obowiązku prowadzenia obowiązku prowadzenia rejestru działalności dla całego gospodarstwa w odniesieniu do wszystkich stosowanych nawozów.

Z porównania wynika, że nowymi pakietami wprowadzonymi w PROW 2007-2013 była ochrona zagrożonych gatunków ptaków i siedlisk przyrodniczych leżących poza obszarami Natura 2000 i ta sama ochrona obowiązywała na obszarach położonych na terenie Natura 2000. Dla tych dwóch pakietów przewidziano 19 wariantów, najwięcej (10) w pakiecie ochrona na obszarach Natura 2000. Wyjście ze 
wsparciem poza obszary Natura 2000 miało na celu poszerzenie tych obszarów, czego domagała się Unia Europejska.

Tabela 1

Liczba beneficjentów i kwot płatności dla obszarów Natura 2000 (PROW 2007-2013)

\begin{tabular}{|c|c|c|c|c|c|c|c|c|c|c|}
\hline \multirow[b]{2}{*}{ Województwo } & \multicolumn{2}{|c|}{$\begin{array}{l}\text { Program rolno- } \\
\text { środowiskowy }\end{array}$} & \multicolumn{2}{|c|}{$\begin{array}{c}\text { Ochrona } \\
\text { siedlisk poza } \\
\text { obszarami } \\
\text { Natura } 2000\end{array}$} & \multicolumn{2}{|c|}{\begin{tabular}{|c|} 
Udział \\
w stosunku \\
do programu \\
rolnośrodowi- \\
skowego
\end{tabular}} & \multicolumn{2}{|c|}{$\begin{array}{c}\text { Ochrona } \\
\text { siedlisk na } \\
\text { obszarach } \\
\text { Natura } 2000\end{array}$} & \multicolumn{2}{|c|}{$\begin{array}{c}\text { Udział } \\
\text { w stosunku } \\
\text { do programu } \\
\text { rolnośrodowi- } \\
\text { skowego }\end{array}$} \\
\hline & 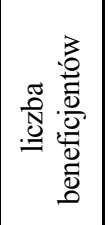 & 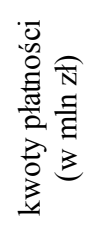 & 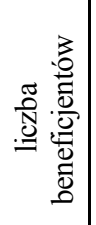 & 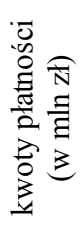 & 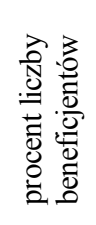 & 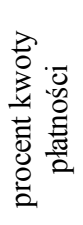 & 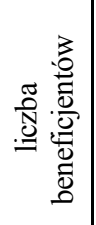 & 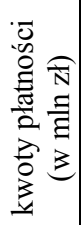 & 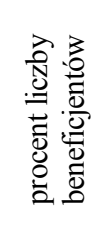 & 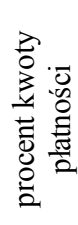 \\
\hline Dolnośla & 21044 & 378,8 & 1208 & 49,4 & 5,7 & 13,0 & 1015 & 58,4 & 4,8 & 15,4 \\
\hline Kujawsko-po & \begin{tabular}{|l|}
47990 \\
\end{tabular} & 551,4 & 296 & 9,8 & 0,6 & 1,8 & 280 & 14,6 & 0,6 & 2,6 \\
\hline Lubelskie & 70881 & 606,2 & 3224 & $\overline{74,8}$ & 4,5 & 12,3 & 2102 & 77,4 & 2,9 & 12,8 \\
\hline Lubuskie & 16944 & 439,7 & 813 & 47,1 & 4,8 & 10,7 & 958 & 110,1 & 5,6 & 25 \\
\hline Łódzkie & 22612 & 149,3 & 225 & 6,0 & 1,0 & 4,0 & 308 & 8,0 & 1,4 & 5,3 \\
\hline Małopolskie & 28568 & 189,2 & 327 & 8,1 & 1,3 & 4,3 & 516 & 20,0 & 1,8 & 10,5 \\
\hline Mazowieckie & 54777 & 536,5 & 1082 & 43,8 & 2,0 & 8,2 & 1385 & 65,6 & 2,5 & 12,2 \\
\hline Opolskie & 11657 & 164,2 & 119 & 4,1 & 2,5 & 2,5 & 55 & 1,7 & 0,5 & 1 \\
\hline Podkarpackie & 41655 & 353,2 & 2893 & 71,9 & 6,9 & 20,3 & 2531 & 95,6 & 6,1 & 27,1 \\
\hline Podlaskie & 48383 & 522,7 & 1503 & 32,2 & 3,1 & 3,9 & 2667 & 126,1 & 5,5 & 24,1 \\
\hline Pomorskie & 34105 & 529,3 & 1458 & 67,4 & 4,3 & 12,7 & 626 & 27,1 & 1,8 & 5,1 \\
\hline Śląskie & 7566 & 81,7 & 231 & 12,2 & 3,0 & 14,9 & 94 & 6,9 & 1,2 & 8,4 \\
\hline Śsiętokrzyskie & 37154 & 188,8 & 604 & 8,7 & 1,6 & 4,6 & 1013 & 13,9 & 2,7 & 7,4 \\
\hline Warmińsko-mazurskie & 40493 & 744,1 & 1371 & 67,5 & 3,4 & 9,1 & 1089 & 57,5 & 2,7 & 7,8 \\
\hline Wielkopolskie & 51760 & 641,3 & 635 & 33,7 & 1,2 & 5,2 & 987 & 67,8 & 1,9 & 7,2 \\
\hline Zachodniop omorskie & 30927 & 860,4 & 1011 & 72,9 & 3,3 & 8,5 & 1224 & 130,0 & 3,9 & 15,1 \\
\hline Razem & 556516 & 6936,8 & 17000 & 609,6 & 3,0 & 8,8 & 16850 & 880,7 & 3,0 & 12,7 \\
\hline
\end{tabular}

Źródło: System Informacji Zarządczej ARiMR, w części dotyczącej ochrony środowiska poza i na obszarach Natura 2000 niepublikowane dane ARiMR.

W latach 2007-2013 liczba beneficjentów w dwóch wariantach związanych z siecią Natura 2000 pozostawała na podobnym poziomie (17 tys.), co stanowiło $3,0 \% \mathrm{w}$ stosunku do całego programu rolnośrodowiskowego. Występowało zjawisko pewnej koncentracji działań na terenie woj. lubelskiego, podkarpackiego, podlaskiego, warmińsko-mazurskiego i mazowieckiego. Kwoty płatności były wyższe W wariancie ochrona siedlisk położonych na obszarze Natura 2000 (880,7 mln zf), w stosunku do wariantu ochrona siedlisk poza obszarami Natura $2000(609,6 \mathrm{mln}$ 
zł). Na jedno działanie przypadało 52,3 tys. zł w pierwszym wariancie, zaś 35,8 tys. zł w drugim wariancie.

Płatności rolnośrodowiskowe wypłacane były w formie zryczałtowanej i stanowily rekompensatę za utracony dochód oraz za dodatkowo poniesione koszty. Przyznawane są rolnikom, którzy dobrowolnie przyjmują na siebie zobowiązania zawarte $\mathrm{w}$ pakiecie rolnośrodowiskowym. Płatności te były pomocą wieloletnią, wypłacaną corocznie, po wykonaniu określonego zestawu zadań w ramach danego wariantu. Były określane w przeliczeniu na hektar powierzchni, sztukę zwierzęcia gospodarskiego lub metr bieżący elementu liniowego. Płatności rolnośrodowiskowe były udzielane do gruntów rolnych użytkowanych jako grunty orne, łąki, pastwiska oraz sady.

\section{Właściwości PROW 2014-2020 w sprawie inwestycji w gospodar- stwach położonych na obszarach Natura 2000}

Gospodarstwa rolne położone na obszarach Natura 2000 napotykają na szereg wymogów związanych z obowiązkiem realizacji zadań ochronnych przewidzianych dla danego terenu. $\mathrm{Z}$ uwagi na fakt, że plany ochrony odnoszą się do gospodarowania na trwałych użytkach rolnych, stąd wsparcie skierowane zostało na inwestycje związane $\mathrm{z}$ rolniczym wykorzystaniem ląk i pastwisk oraz z produkcją zwierzęcą, przy zastrzeżeniu prowadzenia produkcji w powiązaniu $\mathrm{z}$ wymogami ochrony środowiska.

Grupą docelową pomocy udzielanej w ramach działania mogą być producenci rolni działający, po pierwsze jako osoba fizyczna, po drugie jako osoba prawna lub prowadząca działalność w oparciu o umowę spółki cywilnej. Podstawowym wymogiem jest, aby podmioty ubiegające się o wsparcie prowadzily w gospodarstwie położonym na Natura 2000, działalność rolniczą w zakresie produkcji zwierzęcej. Gospodarstwo rolne powinno dysponować powierzchnią użytków rolnych obejmująca co najmniej 1 ha.

W ramach omawianego instrumentu finansowego producenci rolni ubiegający się o pomoc mogą uzyskać wsparcie polegające na dofinansowaniu inwestycji, które służą dostosowaniu gospodarstw do wymogów wprowadzonych programami działań dla sieci Natura 2000. W zakres inwestycji wchodzi zakup sprzętu do produkcji i zbioru roślin na trwałych użytkach zielonych, w tym urządzeń do usuwania drzew i krzewów i roślin inwazyjnych. Drugi rodzaj inwestycji związany jest z budową budynków inwentarskich i wyposażenia do produkcji zwierzęcej, 
celu rozwoju chowu zwierząt trawożernych, zapewniających racjonalne wykorzystanie użytków zielonych w gospodarstwie.

W zamian za wsparcie rolnicy zobowiązani zostali, by przez minimalny okres co najmniej pięciu lat, stosowali przyjazne dla środowiska techniki rolnicze, które wykraczają poza zobowiązania prawne. W zamian rolnicy mają otrzymywać płatności, które zapewniają rekompensatę dodatkowych kosztów i utraconych dochodów wynikających ze stosowania tych przyjaznych środowisku praktyk rolniczych. Środki inwestycyjne odgrywają kluczową rolę dla spełnienia zapotrzebowania społeczeństwa na efekty środowiskowe przewidziane przez rolnictwo. Program Natura 2000 przyczyniać się ma do rozbudowania różnych systemów gospodarowania, powstawania mozaiki krajobrazów, generowania przyjaznych dla środowiska nowych środowisk przyrodniczych.

Wysokość wsparcia inwestycyjnego w przypadku producentów rolnych wynosi do 50\% kosztów kwalifikowanych, zaś w przypadku młodych rolników ten poziom wzrasta do $60 \%$ kosztów kwalifikowanych. Maksymalna wysokość pomocy udzielonej jednemu beneficjentowi i na jedno gospodarstwo nie może przekroczyć 200 tys. zł w przypadku inwestycji niezwiązanej z budową lub modernizacją budynków inwentarskich oraz 500 tys. zł w przypadku, gdy operacja obejmuje budowę, modernizację lub adaptację istniejących budynków inwentarskich. Preferowane będą gospodarstwa posiadające duże powierzchnie trwałych użytków rolnych i to położonych na obszarze Natura 2000. Ze względu na możliwość stosowania nowych rozwiązań technologicznych w zakresie ochrony środowiska, planowany typ operacji ma też wymiar proinnowacyjny oraz wpisuje się w cele przekrojowe $\mathrm{W}$ zakresie środowiska i klimatu. W gospodarstwie powinna być zachowana obsada zwierząt, wynikająca z planu zadań ochronnych na poziomie maksymalnie $2 \mathrm{DJP} / \mathrm{ha}$.

Ze względu na to, że w Polsce od 2014 r. występują dwie kategorie regionów (poziom NUTS 2) województwo mazowieckie, które jako region po raz pierwszy przekroczyło poziom 75\% poziomu PKB na mieszkańca w relacji do średniej unijnej, dlatego instrumenty finansowe ustalone zostały odrębnie dla 15 województw i odrębnie dla jednego województwo mazowieckiego. W związku z tym, w przypadku naborów krajowych, informacja o kolejności przysługiwania pomocy będzie obejmowała kolejność dla województwa mazowieckiego oraz kolejność dla pozostałych województw łącznie. W operacji typu inwestycje w gospodarstwach położonych na obszarach Natura 2000 przewidziano wysokość limitów środków w wysokości 39,1 mln euro, co stanowi 0,4\% ogólnego budżetu PROW 2014-20209.

${ }^{9}$ PROW, 2015 


\section{Podsumowanie}

Program na rzecz utrzymania różnorodności biologicznej zmierzał nie tylko do zachowania dotychczasowych zasobów przyrodniczych, ale także do odtwarzania siedlisk utraconych poprzez działalność człowieka. Celem sieci Natura 2000 było zapewnienie długoterminowego przetrwania najcenniejszych i zagrożonych gatunków i siedlisk. W oparciu o dyrektywę siedliskową i ptasią dążono do tworzenia sieci Natura 2000, która na terenach wiejskich przyczyniła się do innego sposobu użytkowania ziemi. Koszty funkcjonowania rolników na użytkach rolnych będących objętych regulacjami prawnymi, były częściowo rekompensowane przez środki EFRROW. Nie zawsze po te środki rolnicy sięgali, a ponadto niekiedy były trudno dostępne, gdyż rolnicy nie byli w stanie wskazać korzyści jakie przynosi takie użytkowanie gruntów rolnych. Można było raczej mówić o korzyściach społecznogospodarczych dla całego regionu (turystyka, rekreacja). Restrykcjom podlegała głównie działalność inwestycyjna, która mogła znacząco negatywnie oddziaływać na siedlisko. Wyjątki od reguły stanowily inwestycje konieczne z punktu widzenia społecznego i gospodarczego, dla których nie było żadnej alternatywy. Obszary chronione to miejsca, gdzie ludzie i otaczająca ich przyroda powinni egzystować w symbiozie, $\mathrm{z}$ tego też powodu działalność człowieka, która w sposób znaczący nie oddziałuje negatywnie na środowisko jest dozwolona.

Instrumenty wsparcia finansowego pochodzily z UE, w tym zwłaszcza z funduszu spójności. Koszty utrzymania unijnej sieci Natura 2000, stanowią jedynie ułamek korzyści gospodarczych, jakie przynosi przyroda. W przypadku rolnictwa wsparcie sieci znalazło swoje odzwierciedlenie w EFRROW, który realizowano za pośrednictwem działań rolnośrodowiskowych. Jedną z dodatkowych praktyk rolnośrodowiskowych wspierających różnorodność biologiczną stanowiło rolnictwo ekologiczne, które tworzyło wartość dodaną do produktów rolnych. Natomiast same poczynania inwestycyjne na obszarze Natura 2000 zaliczano do grupy działań o charakterze nieprodukcyjnym, bez konieczności generowania wartości dodanej. Sieć Natura 2000 łącznie z parkami narodowymi, rezerwatami przyrody, parkami krajobrazowymi, obszarami chronionego krajobrazu i innymi formami ochrony przyrody, stanowią trwałe podstawy właściwej ochrony przyrody. 


\section{Bibliografia}

Coffey C., Richartz S., The EU Habitats Directive, Generating Strong Responses, Institute for European Environmental Policy, 2003.

Dyrektywa Rady 92/43/EWG z dnia 21 maja 1992 r. w sprawie ochrony siedlisk przyrodniczych oraz dzikiej fauny i flory.

Dyrektywa Rady z dnia 2 kwietnia 1979 r. w sprawie ochrony dzikiego ptactwa.

Kaługa I., Korzyści dla rolnictwa wynikajace z gospodarowania na obszarach Natura 2000, Ministers two Środowiska, 2009.

Mehtata J., Vuorisalo T, Conservation policy and the EU Habitats Directive: favorable conservation status as a measure of conservation success, Environmental Policy and Governance, 2007.

Program Rozwoju Obszarów Wiejskich, MRiRW, 2014.

Rozporządzenie Rady (WE) nr 1698/2005 z dnia 20 września 2005 r. w sprawie wsparcia rozwoju obszarów wiejskich przez Europejski Fundusz Rolny na rzecz Rozwoju Obszarów Wiejskich (EFRROW).

Rozporządzenie Parlamentu Europejskiego i Rady (UE) NR 1305/2013 z dnia 17 grudnia 2013 r. w sprawie wsparcia rozwoju obszarów wiejskich przez Europejski Fundusz Rolny na rzecz Rozwoju Obszarów Wiejskich (EFRROW) i uchylające rozporządzenie Rady (WE) nr 1698/2005.

Ustawa z dnia 16 kwietnia 2004 r. o ochronie przyrody.

\section{Properties if investments in holdings in Nature 2000 areas}

\section{Summary}

The study analyzes the problematics of undertaken actions related to the creation of the Nature 2000 network and the range of payments in the Rural Development Programs. Poland, implementing the habitats' directive and the birds' ones (2004) designated Nature 2000 sites, which are important factors in natural environment protection. In the rural development programming (2007-2013) Natura 2000 program was realized with use of agri-environment payments. In the current long-term financial perspective (20142020) there were pointed special actions related to investments in farms located in Natura 2000. In accepted in RDP 2014-2020 action associated with investments in Natura 2000 areas, there was directed support for farmers with less intensive livestock production. The amount of support is $50 \%$ of eligible costs, and for young farmers is $60 \%$. The maximum amount of aid granted to a single beneficiary and to one farm was set at 200 thous. PLN, for investments -500 thousand. PLN. In the RDP 2014-2020 there were allocated funds in total amount of 39,1 mio. PLN for investemnts in farms located in Nature 2000 areas, what was $0,4 \%$ of total budget. 